\title{
Induced Abortion Indicator
}

National Cancer Institute

\section{Source}

National Cancer Institute. Induced Abortion Indicator. NCI Thesaurus. Code C156588.

An indication as to whether the female subject has had an induced abortion procedure. 